\title{
Subchronic Exposure of Heat-induced Food Contaminant Acrolein: Evaluation of Toxicological Effects on Male Reproductive Tract from Weaning to Postpuberty
}

\author{
Isı ile Indüklenen Gıda Kirleticisi Akroleine Subkronik Maruziyet: \\ Sütten kesilme ile Postpubertal Dönemdeki Erkek Sıçanlar \\ Üzerindeki Toksikolojik Etkilerin Değerlendirilmesi
}

Research Article

Elif Karacaoğlu* and Güldeniz Selmanoğlu

Hacettepe University, Faculty of Science, Department of Biology, Beytepe, Ankara, Turkey.

\section{A B S TR AC T}

\begin{abstract}
A crolein is a very electrophilic $\alpha, \beta$ aldehyde, formed in foods by thermal processing of amino acids, fats and carbohydrates. Due to lack of toxicological information about acrolein exposure, male rats from weaning to postpubertal period was evaluated in terms of reproductive toxicity. Weaning male rats were orally exposed to $0.5,1$ and $2 \mathrm{mg} / \mathrm{kg} /$ day acrolein for 90 days. Serum testosterone and lutenizing hormone (LH) levels were measured and sperm paremeters were evaluated. Reproductive organs were examined histopathologically. Although several histopathological alterations were observed in reproductive organs of rats in acrolein treatment groups, no changes were observed in hormone levels and sperm count.
\end{abstract}

Key Words

Acrolein, reproductive system, sperm toxicity, hormone.

\section{Ö z}

\begin{abstract}
Cok elektrofilik bir $\alpha, \beta$ aldehit olan akrolein besinlerde amino asitlerin, yağların ve karbohidratların ısıl işlem görmesi ile oluşmaktadır. Bu çalışmada, akrolein maruziyetinin sütten kesilmeden postpubertal döneme kadar olan süreçteki erkek sıçanların üreme sistemi üzerindeki toksikolojik etkilerini değerlendirmeyi amaçlamaktadır. Bu amaçla, sütten kesilen erkek sıçanlar 90 gün boyunca $0.5,1$ ve 2 mg/kg/gün akroleine ağız yoluyla yolla maruz bırakılmışlardır. Serum testosteron ve lütenleştirici hormon (LH) düzeyleri ölçülmüş, sperm parametreleri değerlendirilmiştir. Üreme sistemine ait organlar histopatolojik olarak incelenmiştir. Akroleine maruz kalan sıçanların üreme sistemi dokularında çeşitli histopatolojik değişiklikler gözlenmesine rağmen, hormon düzeylerinde ve sperm sayılarında herhangi bir değişiklik gözlenmemiştir.
\end{abstract}

Anahtar Kelimeler

Akrolein, üreme sistemi, sperm toksisitesi, hormon.

Article History: Received: Apr 12, 2017; Revised: May 21, 2017; Accepted: July 17, 2017; Available Online: Dec 25, 2017. DOI: 10.15671/HJBC.2018.204

Correspondence to: E. Karacaoğlu, Hacettepe University, Faculty of Science, Department of Biology, Beytepe, Ankara, Turkey Tel: +903127805038

Fax: +903122992028

E-Mail: elifkush@hacettepe.edu.tr 


\section{INTRODUCTION}

A crolein is a very electrophilic $\alpha, \beta$ aldehyde [1] and is formed in foods by thermal processing of amino acids, fats and carbohydrates. It can be formed in carbohydrate-rich foods by Maillard reaction (chemical reaction occurs between carbonyl groups of reducing sugars and amino group of amino acids or proteins, known also as non-enzymatic browning reaction). Its occurence was determined in fruits and vegetables such as raspberries, grapes, strawberries, tomatoes and also fish, cheese and in some beverages for instance wine and spirit [2]. Eventually, acrolein exposure could be via consumption of various foods. Human also may expose to acrolein by various routes such as industrial, environmental and therapeutic situations. On the other hand acrolein is commonly used as a pesticide, it is known to be added to water supplies of industrial plants and irrigation canals for controlling plant and algae growth [3]. It is potentially dangerous because it is used as a herbicide and found in cigarette smoke, in the exhaust and vapours of overheated cooking oil [1]. Different source of acrolein is metabolization of oxazaphosphorines, besides it can be generated endogenously throughout lipid peroxidation [4].

Acrolein metabolites such as glycidaldehyde, glycerinaldehyde and acrylic acid were speculated to cause toxicological effects of acrolein [5]. Its toxicity mechanism was asserted as increased levels of protein/DNA adducts, intervention with cell signalling pathways and depletion of glutathione (GSH) levels [6]. The $\mathrm{LD}_{50}$ of acrolein has been reported as 7 and $46 \mathrm{mg} / \mathrm{kg}$ for mice, rats and hamsters [7].

Oral exposure of acrolein was reported to cause gastrointestinal diseases including gastric ulcers or gastric bleeding $[5,8]$. However, Faroon et al. have reported that no reproductive effects was evaluated after oral exposure [5]. Children, compared to adults, are known to be more susceptible to chemical contaminants because of their unique activities. Physiologically, they are susceptible to adverse ef fects because they have undeveloped or developing organs and systems such as reproductive system [9].
In the present study, due to lack of toxicological information about reproductive tract of male rats, acrolein exposure to young male rats from weaning to postpubertal period was evaluated in terms of reproductive toxicity.

\section{MATERIAL AND METHODS}

\section{Chemicals, Animals and Treatment}

Acrolein (CAS no. 107-02-8) and metylcellulose (CAS no. 9004-67-5) were purchased from Sigma, USA. This study was endorsed by the local animal experimentation ethic commitee of $\mathrm{Ha}$ cettepe University (Approval number: 2010/11-5). Three-four week aged Wistar male rats were acclimated to our laboratory conditions before the experiment. Rats were placed into polycarbonate cages and maintained under a controlled environment at $12 \mathrm{~h}$ light $/ 12 \mathrm{~h}$ dark cycle at $20.6 \pm 1.3^{\circ} \mathrm{C}$, $50.3 \pm 3.9 \%$ relative humidity throughout the experimental period. Wistar rats were divided into 5 groups including 10 animals each groups: three of them were treatment groups, one control group and one vehicle (control) group. Rats in control groups were fed by standard feed and water ad libitum. In addition, animals in vehicle control group were fed by methylcellulose. Acrolein was orally administered to rats at doses $0.5,1$ and 2 $\mathrm{mg} / \mathrm{kg} /$ day by dissolving in methylcellulose for 90 days. Body weights of animals were recorded weekly. Animals were sacrified by cervical dislocation at the end of the administration period.

\section{Sperm Analyses}

Cauda epididymis was put into $1 \mathrm{ml}$ physiologic saline solution, cut into small pieces gently and incubated for $15 \mathrm{~min}$ at $37^{\circ} \mathrm{C}$ in order to make spermatozoa separated from the epididymis. Afterward, the epididymal sperm was diluted and sperms were stained with $1 \%$ Eosin Y. Sperm sample was smeared onto a slide and abnormal sperms were evaluated [10] by counting 200 sperms per cauda epididymis. Additionally, sperm counts were evaluated by Neubauer's chamber. Sperm number per gram cauda epididymis were calculated because epididymal weight was reported to be changed with regard to age and body weight [11]. 


\section{Hormone Analysis}

Blood samples were collected from hearts of the rats and centrifuged for $15 \mathrm{~min}$ at $4^{\circ} \mathrm{C}$ at 3,500 rpm. Serum samples were seperated and kept at $-80^{\circ} \mathrm{C}$ until hormone analysis. Serum testosterone and LH levels were measured by using commercial Elisa kits (Endocrine Technologies, USA). Absorbance was measured at $450 \mathrm{~nm}$ with a microplate spectrophotometer (BIO-TEK $\mu$ Quant, BIO-TEK Instruments, USA).

\section{Histopathological Examination}

Reproductive organs including testis, epididymis and accesory glands such as seminal vesicle and prostate gland were dissected out immediately, observed and weighted at the end of the administration period. Relative organ weights were calculated. Tissue samples were fixed in Bouin's solution. All tissue samples were dehydrated, embedded in parafin blocks, afterwards, $5 \mu \mathrm{m}$-thick sections were stained with $\mathrm{H} \& \mathrm{E}$ and slides were examined under the light microscopy.

\section{Statistical Analysis}

Data were analysed by Statistica software. Results were expressed as mean \pm standart error of mean
(SEM). One-way analysis of variance (ANOVA) was carried out to compare differences between groups with Tukey and Games-Howell post-hoc tests. Fisher's exact test was used to determine the differences between the histopathological incidences of the groups. The significance was assigned at $\mathrm{P} \leq 0.05$.

\section{RESULTS}

\section{Absolute and Relative Organ Weights}

No statistically differences were observed in absolute and relative organ weights in testis, epididymis and prostate gland of acrolein treated three groups. Seminal vesicle relative weights increased in $1 \mathrm{mg} / \mathrm{kg}$ and $2 \mathrm{mg} / \mathrm{kg}$ acrolein treatment groups compared with control and vehicle control group. Data was shown in Table 1.

\section{Sperm Counts, Sperm Morphology and Hormone Levels}

Epididymal sperm counts decreased in acrolein treatment groups. However, decrease was not statistically significant. Percentage of abnormal sperm increased in 1 and $2 \mathrm{mg} / \mathrm{kg}$ acrolein treatment groups; however, increase in $2 \mathrm{mg} / \mathrm{kg}$ acro-

Table 1. Organ weights of rats in control and treatment groups.

\begin{tabular}{|c|c|c|c|c|c|}
\hline & \multirow[b]{2}{*}{ Control } & \multirow[b]{2}{*}{ Vehicle Control } & \multicolumn{3}{|c|}{ Acrolein } \\
\hline & & & $0.5 \mathrm{mg} / \mathrm{kg}$ & $1 \mathrm{mg} / \mathrm{kg}$ & $2 \mathrm{mg} / \mathrm{kg}$ \\
\hline \multicolumn{6}{|l|}{ Right Testis } \\
\hline Absolute (g) & $1.829 \pm 0.051$ & $1.779 \pm 0.079$ & $1.756 \pm 0.082$ & $1.835 \pm 0.038$ & $1.912 \pm 0.068$ \\
\hline Relative & $0.0049 \pm 0.000$ & $0.0050 \pm 0.001$ & $0.0045 \pm 0.000$ & $0.0053 \pm 0.000$ & $0.0053 \pm 0.001$ \\
\hline \multicolumn{6}{|l|}{ Left Testis } \\
\hline Absolute (g) & $1.854 \pm 0.051$ & $1.793 \pm 0.078$ & $1.780 \pm 0.100$ & $1.826 \pm 0.052$ & $1.891 \pm 0.054$ \\
\hline Relative & $0.005 \pm 0.000$ & $0.0051 \pm 0.001$ & $0.0046 \pm 0.000$ & $0.0053 \pm 0.000$ & $0.0052 \pm 0.000$ \\
\hline \multicolumn{6}{|l|}{ Epididymis } \\
\hline Absolute (g) & $0.680 \pm 0.018$ & $0.683 \pm 0.026$ & $0.652 \pm 0.019$ & $0.672 \pm 0.011$ & $0.701 \pm 0.016$ \\
\hline Relative & $0.0019 \pm 0.000$ & $0.0020 \pm 0.001$ & $0.0017 \pm 0.000$ & $0.0020 \pm 0.000$ & $0.0019 \pm 0.000$ \\
\hline \multicolumn{6}{|c|}{ Prostate gland } \\
\hline Absolute (g) & $0.488 \pm 0.031$ & $0.470 \pm 0.042$ & $0.456 \pm 0.033$ & $0.0437 \pm 0.025$ & $0.408 \pm 0.035$ \\
\hline Relative & $0.0013 \pm 0.000$ & $0.0013 \pm 0.000$ & $0.0011 \pm 0.000$ & $0.0013 \pm 0.000$ & $0.0011 \pm 0.000$ \\
\hline \multicolumn{6}{|c|}{ Seminal vesicle } \\
\hline Absolute (g) & $0.806 \pm 0.050$ & $0.900 \pm 0.061$ & $1.047 \pm 0.098$ & $1.157 \pm 0.051$ & $1.154 \pm 0.052$ \\
\hline Relative & $0.0022 \pm 0.000$ & $0.0025 \pm 0.00$ & $0.0027 \pm 0.000$ & $0.0034 \pm 0.000^{a, b}$ & $0.0032 \pm 0.000^{a, b}$ \\
\hline
\end{tabular}

Data were expressed as mean \pm SEM, $\mathrm{P} \leq 0.05$.

aSignificantly different from control group.

bSignificantly different from vehicle control group. 
Table 2. Sperm counts and morphology, and serum hormone concentrations of rats in treatment groups.

\begin{tabular}{lccccc}
\hline & & & & Acrolein \\
\cline { 4 - 6 } & Control & Vehicle Control & $0.5 \mathrm{mg} / \mathrm{kg}$ & $1 \mathrm{mg} / \mathrm{kg}$ & $2 \mathrm{mg} / \mathrm{kg}$ \\
\hline $\begin{array}{l}\text { Sperm count/gr epididymis } \\
\left(\mathrm{x} 10^{6}\right)\end{array}$ & $251.34 \pm 56.60$ & $154.22 \pm 14.77$ & $210.23 \pm 25.08$ & $163.59 \pm 20.47$ & $178.67 \pm 12.81$ \\
\hline Abnormal sperm \% & $2.78 \pm 0.66$ & $4.05 \pm 0.61$ & $4.01 \pm 0.72$ & $5.50 \pm 0.81$ & $7.12 \pm 2.32^{\mathrm{a}}$ \\
\hline LH (ng/ml) & $6.33 \pm 0.83$ & $7.82 \pm 1.01$ & $8.55 \pm 0.99$ & $7.54 \pm 0.87$ & $9.45 \pm 1.06$ \\
\hline Testosterone (ng/ml) & $1.67 \pm 0.20$ & $1.28 \pm 0.22$ & $2.21 \pm 0.26$ & $2.28 \pm 0.11$ & $1.46 \pm 0.21$ \\
\hline Data are expressed as mean \pm se, & & & & & \\
\hline
\end{tabular}

Data are expressed as mean \pm se,

aSignificantly different from control group.

Table 3. Histopatological incidences in reproductive tissues of rats in control and treatment groups.

\begin{tabular}{|c|c|c|c|c|c|}
\hline & \multirow[b]{2}{*}{ Control } & \multirow[b]{2}{*}{ Vehicle Control } & \multicolumn{3}{|c|}{ Acrolein } \\
\hline & & & $0.5 \mathrm{mg} / \mathrm{kg}$ & $1 \mathrm{mg} / \mathrm{kg}$ & $2 \mathrm{mg} / \mathrm{kg}$ \\
\hline \multicolumn{6}{|l|}{ Testis } \\
\hline Sloughing germ cells & $0 / 10$ & $0 / 10$ & $3 / 8$ & $1 / 9$ & $0 / 9$ \\
\hline Edema & $0 / 10$ & $0 / 10$ & $3 / 8$ & $2 / 9$ & $\mathrm{a}, \mathrm{b} 5 / 9$ \\
\hline Multinucleated giant cell & $0 / 10$ & $0 / 10$ & $1 / 8$ & $0 / 9$ & $1 / 9$ \\
\hline Disorganization of tubules & $0 / 10$ & $0 / 10$ & $2 / 8$ & $a, b 6 / 9$ & $a, b 7 / 9$ \\
\hline $\begin{array}{l}\text { Epididymis } \\
\text { Mononuclear cell infiltration }\end{array}$ & $0 / 10$ & $0 / 10$ & $\mathrm{a}, \mathrm{b} 7 / 8$ & $a, b 7 / 9$ & $a, b 7 / 9$ \\
\hline Germ cells in lumen & $0 / 10$ & $0 / 10$ & $a, b 5 / 8$ & ${ }^{c} 1 / 9$ & ${ }^{\circ} 0 / 9$ \\
\hline Increase in connective tissue & $0 / 10$ & $0 / 10$ & $0 / 8$ & $3 / 9$ & $a, b, c 7 / 9$ \\
\hline $\begin{array}{l}\text { Prostat gland } \\
\text { Mononuclear cell infiltration }\end{array}$ & $0 / 10$ & $0 / 10$ & $3 / 8$ & $2 / 9$ & $\mathrm{a}, \mathrm{b} 6 / 9$ \\
\hline Congestion & $0 / 10$ & $0 / 10$ & $2 / 8$ & $2 / 9$ & $1 / 9$ \\
\hline Edema & $0 / 10$ & $0 / 10$ & $1 / 8$ & $0 / 9$ & $2 / 9$ \\
\hline
\end{tabular}

Data are expressed as pathological finding/number of rats in control and treatment groups. Fisher's exact test; $P \leq 0.05$.

a Significantly different from control group.

b Significantly different from vehicle control group.

c Significantly different from $0.5 \mathrm{mg} / \mathrm{kg} /$ day acrolein

lein treatment group was statistically significant. Serum LH and testosterone concentrations did not change with acrolein treatment. Data was shown in Table 2.

\section{Histopathological Examination}

Testis of rats belonging to control group had normal histology with organized seminiferous tubules and connective tissue. Testis tissues of rats treated with acrolein had some minor histopathological alterations in seminiferous tubules including interstitial connective tissue. Table 3 shows the incidences of histopathological findings. While there were no histopathological changes in seminal vesicle, sloughing germ cells, edema and disorganization of tubules in testis were the main findings in all dose groups. Edema in $2 \mathrm{mg} / \mathrm{kg}$ dose group and disorganization of tubules in 1 and $2 \mathrm{mg} / \mathrm{kg}$ dose groups were statistically significant compared with control groups. Figure 1 shows the light microscopic images in testis of rats. Multinucleated giant cell also was observed in 0.5 and $2 \mathrm{mg} / \mathrm{kg}$ acrolein groups, however it was not statistically significant. 


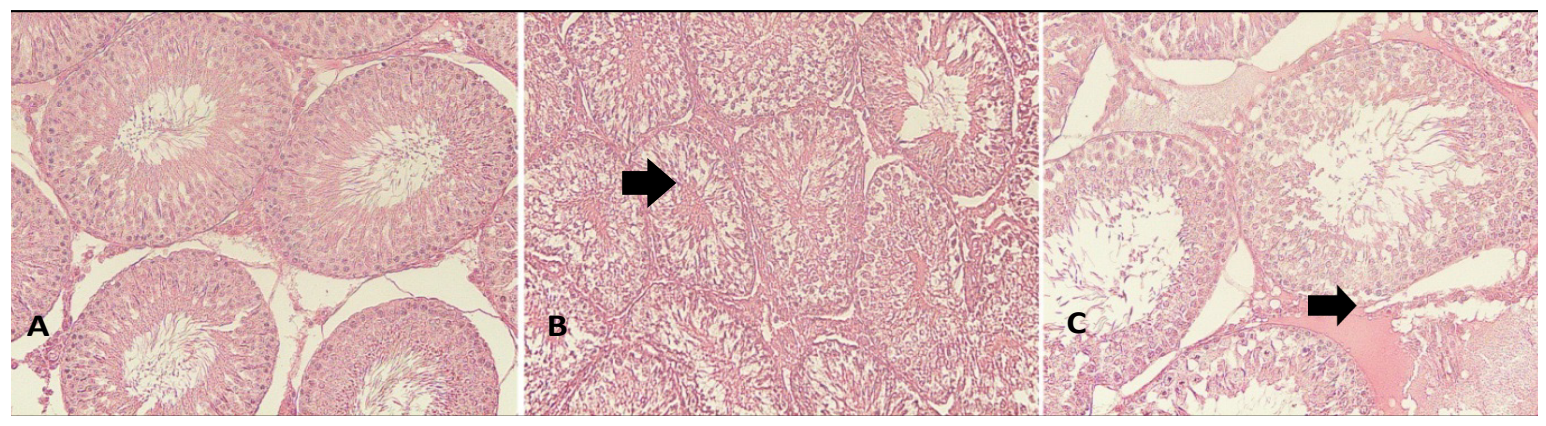

Figure 1. Light microscopic images of testis, A) Control group, B) Disorganization of tubules in $0.5 \mathrm{mg} / \mathrm{kg}$ acrolein treatment group, C) Edema in $2 \mathrm{mg} / \mathrm{kg}$ acrolein treatment group. H\&E staining, 100x.
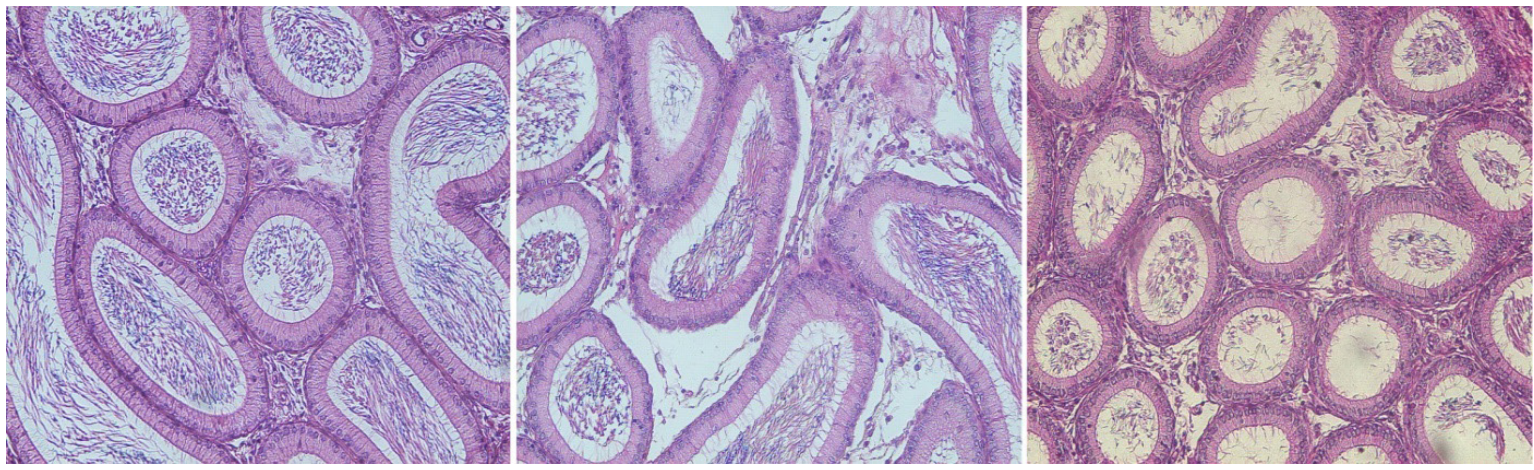

Figure 2. Light microscopic images of epididymis, A) Control group, B) Inflammation in caput epididymis in $0.5 \mathrm{mg} / \mathrm{kg}$ acrolein treatment group, (à), C) Germ cells in the lumen in $1 \mathrm{mg} / \mathrm{kg}$ acrolein treatment group (à). H\&E staining, 100x.

Epididymis of the rats in control group had normal histoarchitecture. Epididymal tissue of the acrolein treated rats were affected by acrolein treatment. Figure 2 shows histopathological findings in epididymis of rats. Mononuclear cell infiltration was the dominant finding in all dose groups and statistically significant when compared to control groups. Germ cells in the lumen were observed in 0.5 and 1 $\mathrm{mg} / \mathrm{kg}$ acrolein dose groups, it was statistically significant in $0.5 \mathrm{mg} / \mathrm{kg}$ acrolein dose group compared with control groups. Additionally, germ cells in the lumen in 1 and $2 \mathrm{mg} / \mathrm{kg}$ acrolein dose groups were statistically significant when compared to $0.5 \mathrm{mg} /$ $\mathrm{kg}$ acrolein dose group. Another finding in epididiymis was an increase in connective tissue. It was observed in 1 and $2 \mathrm{mg} / \mathrm{kg}$ acrolein dose groups, but it was statistically significant in only $2 \mathrm{mg} / \mathrm{kg}$ acrolein dose group when compared to control groups and $0.5 \mathrm{mg} / \mathrm{kg}$ acrolein dose group.

Histoarchitecture of the prostate gland of rats in control group was normal with sufficient amount of glandular secretions. In prostate gland of rats in treatment groups, mononuclear cell infiltration was observed in all dose groups, however it was statistically significant only at $2 \mathrm{mg} / \mathrm{kg}$ ac-

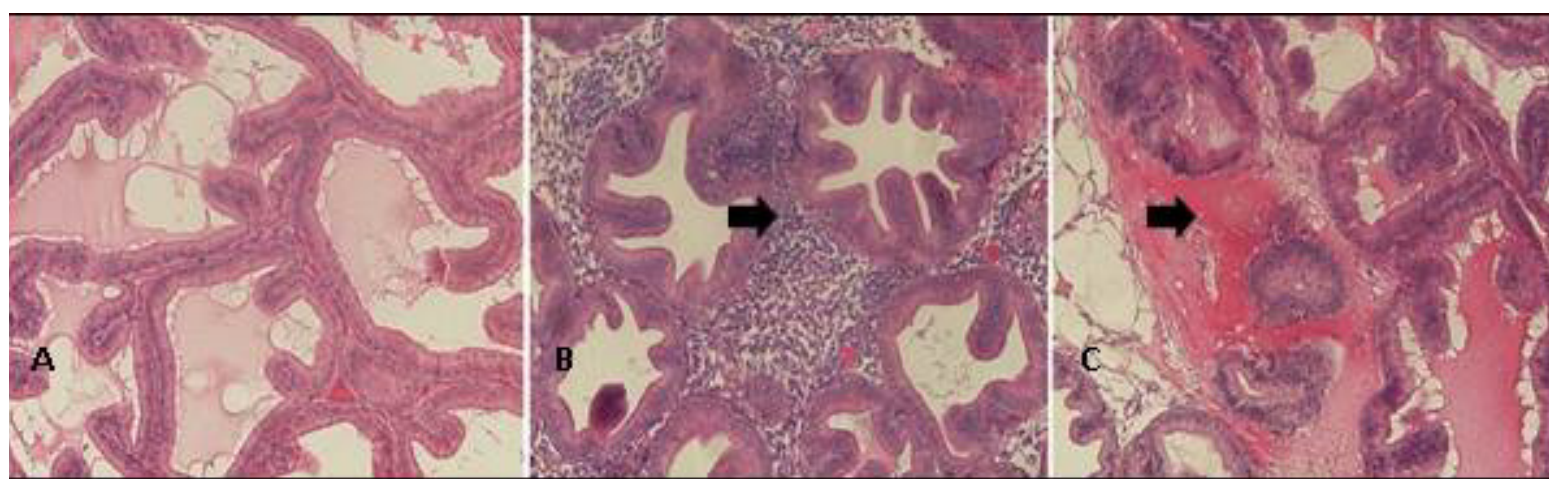

Figure 3. Light microscopic images of prostate gland, A) Control group, B) Inflammation in $0.5 \mathrm{mg} / \mathrm{kg}$ acrolein treatment group, C) Edema in $0.5 \mathrm{mg} / \mathrm{kg}$ in treatment group. H\&E staining, 100x. 
rolein dose group compared with control groups. Congestion and edema were the minor findings in prostate gland, however they were not statistically significant (Figure 3 ).

\section{DISCUSSION}

Recent reports revealed that incidences of testicular cancer and reproductive dysfunctions elevated with chemical exposure existing in the environment [12]. Acrolein as an environmental contaminant is known to cause toxicity in gastrointestinal, respiratory and nervous system $[4,5]$. Additionally, acrolein adducts are taken into consideration to contribute to several pathological situations including diseases in nervous and cardiovascular systems [4,13]. Several reproductive and developmental toxicology studies were conducted with rats and rabbits by acrolein exposure and high doses of acrolein was reported to cause maternal mortality, abortion but it was not reported as developmental toxicant $[14,15]$. However, no data was reported in growing male reproductive toxicity. Due to the lack information about reproductive toxicity, the present study was designed to evaluate the subchronic effects of acrolein on reproductive tract of male rats from weaning to postpuberty. Reproductive tract displays sensitivity to chemicals throughout developmental period than adulthood. For this reason weaning Wistar male rats were administered acrolein at doses of $0.5,1$ and $2 \mathrm{mg} / \mathrm{kg}$ orally for 90 days.

Organ weight and organ body weight ratio are important markers in evaluating toxicity of chemicals [16-18]. Absolute testis weight should indicate the gonadal defects [19], however differentiations in measurements of testicular weight may not mean that there is a particular adverse effect or it does not reveal the toxicity mechanism [20]. In the present study, acrolein exposure did not cause significant changes in absolute and relative weights of testis, epididymis and prostate gland, although relative weight of seminal vesicle increased mildly in $1 \mathrm{mg} /$ $\mathrm{kg}$ and $2 \mathrm{mg} / \mathrm{kg}$ acrolein groups. Changes in relative weights of seminal vesicle reflect the androgen status in many cases [21]. According to our results, although $\mathrm{LH}$ and testosterone levels did not change by acrolein treatment, relative weights of seminal vesicle increased significantly. In this situation, inc- rease in relative weight of seminal vesicle can not to be explained by androgen status, it may be due to body weight changes of acrolein treatment groups or individual differences of rats.

Histopathology is one of the most sensitive parameters in evaluating reproductive system toxicity. Acrolein exposure caused some histopathological changes in testis including sloughing germ cells, disorganization of tubules and edema. It has been reported that sloughing germ cells represent Sertoli cell damage in response to impairment of microtubules and indicating testicular dysfunction [22-24]. Formation of multinucleated germ cells may be due to the germ cell degeneration or nuclear division lack of cytoplasmic separation $[23,25]$. Similarly, in our previous study conducted with a heat-induced food contaminant furan caused also sloughing germ cells and multinucleated germ cells in testis of rats [26]. In this situation, acrolein may have disruptive effect on the spermatogenesis. Epididymis is an organ which spermatozoa aquire motility and capacity to fertilize the oocyte. In reproductive studies epididymal histopathology is as important as testis since edididymis provide crucial information for lately testicular conditions. For instance, germ cells occuring in the lumen of the epididymis represent some testicular changes [27]. Sloughed germ cells in the epididymis were known to be a critical parameter indicating minor spermatogenic disturbances of spermatogenesis. As a result of the acrolein treatment, germ cells were observed in epididymal lumen in a dose independent manner. Age of the rat as well as reproductive status is crucial, due to the fact that small number of germ cells existing in the epididymal lumen is common in prepubertal rats [27]. However, in the present study, this situation may be attributed to acrolein toxicity rather than the age of the rat.

Seminal vesicle and prostate glands play important role on male fertility as accesory organs. As a result of acrolein treatment, seminal vesicle did not change morphologically and histopathologically. However, in prostate gland of rats in acrolein treatment groups, mononuclear infiltration was the major finding. It was reported that inflammation of the prostate gland may be related to focal epithelium atrophy in prostate gland [28]. Additionally, prostate gland is a vulnarable tissue for chronic inflamma- 
tion, however the mechanism is not clearly understood [29]. In this case, mechanism of inflammation in prostate gland is an unknown case.

In reproductive toxicity studies, sperm parameters could present significant information which may reveal the mechanism of toxicity [21]. Sperm morphology was reported to be useful markers in the detection of spermatotoxic substances due to showing the least variable reproductive measurement between individuals $[20,30]$. After acrolein exposure, sperm counts did not change significantly, although percentage of abnormal sperm increased in high dose group. Morphology of the sperm is a marker of quality of the sperm. It has been mentioned that sperm cells which have gross DNA damage may be eliminated naturally, although cells with mild defects may remain alive and considered as abnormal sperm [31]. Increase in number of abnormal sperms was reported to represent deteriorations in spermatogenesis [21,31]. Additionally, it was mentioned that over production of reactive oxygen species in semen may be related to dysregulation of sperm metabolism and morphology [31]. Nevertheless we did not evaluate oxidative stress parameters in the present study.

Testicular functionallity is under control of several gonadotropic hormones including $\mathrm{FSH}, \mathrm{LH}$ and chemical toxicity may be attributed to the changes in hormone levels [32]. Testosterone is known to be essential in functionallity of male accessory organs and maintaining the spermatogenesis. Additionally, lack of testosterone may cause deterioration in spermatogenesis [33]. According to results, acrolein exposure had no effect on serum LH and testosterone levels. We may suggest that toxicity mechanism of acrolein in the reproductive tract of postpubertal male rats did not attribute to the hormone levels.

To our knowledge, this study is the first research evaluating the subchronic reproductive toxicity of acrolein on prepubertal male rats. The results of the current study indicated that oral exposure of acrolein for 90 days caused distinctive changes in reproductive organs such as testis, epididymis and prostate gland in a dose-dependent manner. Further studies in reproductive toxicity are required to designate the underlying mechanism of oral acrolein exposure in prepubertal male rats.

\section{ACKNOWLEDGEMENT}

This study was financially supported by Scientific Research Projects Coordination Unit of Hacettepe University (Project no: $010 D 08601008$ and 013D04601001).

\section{References}

1. J.P. Kehrer, S.S. Biswal, The molecular effects of acrolein, Toxicol. Sci., 57 (2000) 6-15.

2. JF. Stevens, C.S. Maier, Acrolein: sources, metabolism, and biomolecular interactions relevant to human health and disease, Mol. Nutr. Food Res., 52 (2008) 7-25.

3. EPA. Reregistration Eligibilty Decision Document by Acrolein, 2008.

4. M. Rashedinia, P. Lari, K. Abnous, H. Hosseinzadeh, Proteomic analysis of rat cerebral cortex following subchronic acrolein toxicity, Toxicol. Appl. Pharm., 272 (2013) 199-207.

5. O. Faroon, N. Roney, J. Taylor, A. Ashizawa, M.H. Lumpkin, D.J. Plewak, Acrolein health effects, Toxicol. Ind. Health, 24 (2008) 447-490.

6. K. Abraham, S. Andres, R. Palavinskas, K. Berg, K.E. Appel, A. Lampen, Toxicology and risk assessment of acrolein in food, Mol. Nutr. Food Res., 55 (2011) 12771290.

7. R. Gomes, M. Meek, E. Eggleton, Concise International Chemical Assessment Document 43: Acrolein, Geneva: World Health Organization, 2002.

8. S.S. Auerbach, J. Mahler, G.S. Travlos, R.D. Irwin, A comparative 90-day toxicity study of allyl acetate, allyl alcohol and acrolein, Toxicology, 253 (2008) 7988.

9. P.I. Beamer, R.A. Canales, A. Bradman, J.O. Leckie, Farmworker children's residential non-dietary exposure estimates from micro-level activity time series, Environ. Int., 35 (2009) 1202-1209.

10. G. Selmanoğlu, Evaluation of the reproductive toxicity of patulin in growing male rats, Food Chem. Toxicol., 44 (2006) 2019-2024.

11. A. Amin, Ketoconazole-induced testicular damage in rats reduced by Gentiana extract, Exp. Toxicol. Pathol., 59 (2008) 377-384.

12. N. Skakkebaek, E. Rajpert-De Meyts, K. Main, Testicular dysgenesis syndrome: an increasingly common developmental disorder with environmental aspects, Hum. Reprod., 16 (2001) 972-978.

13. G. Aldini, M. Orioli, M. Carini, Protein modification by acrolein: relevance to pathological conditions and inhibition by aldehyde sequestering agents, Mol. Nutr. Food Res., 55 (2011) 1301-1319.

14. R.A. Parent, H.E. Caravello, M.S. Christian, A.M. Hoberman, Developmental toxicity of acrolein in New Zealand white rabbits, Fund. Appl. Toxicol., 20 (1993) 248-256.

15. R.A. Parent, H.E. Caravello, A.M. Hoberman, Reproductive study of acrolein on two generations of rats, Fund. Appl. Toxicol., 19 (1992) 228-237.

16. J.W. Crissman, D.G. Goodman, P.K. Hildebrandt, R.R. Maronpot, D.A. Prater, J.H. Riley, et al., Society of Toxicologic Pathology Guideline, Toxicol. Pathol., 32 (2004) 126-131. 
17. A. Yavasoglu, M.A. Karaaslan, Y. Uyanikgil, F. Sayim, U. Ates, N. Yavasoglu, Toxic effects of anatoxin-a on testes and sperm counts of male mice, Exp. Toxicol. Pathol., 60 (2008) 391-396.

18. E. Tanvir, R. Afroz, M. Chowdhury, S. Gan, N. Karim, M. Islam, et al., A model of chlorpyrifos distribution and its biochemical effects on the liver and kidneys of rats, Hum. Exp. Toxicol., 35 (2016) 991-1004.

19. W.W. Ku, R.E. Chapin, R.N. Wine, B.C. Gladen, Testicular toxicity of boric acid (BA): relationship of dose to lesion development and recovery in the F344 rat, Reprod. Toxicol., 7 (1993) 305-319.

20. EPA. Guidelines for Reproductive Toxicity Risk Assessment. 1996. https://www.epa.gov/sites/ production/files/2014-11/documents/guidelines repro_toxicity.pdf

21. D.M. Creasy, R.E. Chapin. Chapter 59 - Male Reproductive System. In: Haschek WM, Rousseaux CG, Wallig MA, editors. Haschek and Rousseaux's Handbook of Toxicologic Pathology (Third Edition). Boston: Academic Press; (2013). p. 2493-2598.

22. S.G. Kumar, K. Narayana, K. Bairy, U.J. D'Souza, V.P. Samuel, K. Gopalakrishna, Dacarbazine induces genotoxic and cytotoxic germ cell damage with concomitant decrease in testosterone and increase in lactate dehydrogenase concentration in the testis, Mutat. Res-Gen. Toxicol. En., 607 (2006) 240-252.

23. K. Narayana, N. Prashanthi, A. Nayanatara, L.K. Bairy, U.J. DoSouza, An organophosphate insecticide methyl parathion (o-o-dimethyl o-4-nitrophenyl phosphorothioate) induces cytotoxic damage and tubular atrophy in the testis despite elevated testosterone level in the rat, J. Toxicol. Sci., 31 (2006) 177-189.

24. S.S. Oda, Z.K. El-Maddawy, Protective effect of vitamin $\mathrm{E}$ and selenium combination on deltamethrininduced reproductive toxicity in male rats, Exp. Toxicol. Pathol., 64 (2012) 813-819.
25. N.H. Cho, C. Park, Effects of dimethyl methylphosphonate (DMMP) and trimethylphosphate (TMP) on spermatogenesis of rat testis, Yonsei Med. J., 35 (1994) 198-208.

26. E. Karacaoğlu, G. Selmanoğlu, Effects of heat-induced food contaminant furan on reproductive system of male rats from weaning through postpuberty, Food Chem. Toxicol., 48 (2010) 1293-1301.

27. G.L. Foley, Overview of male reproductive pathology, Toxicol. Pathol., 29 (2001) 49-63.

28. A.M. De Marzo, Y. Nakai, W.G. Nelson, editors. Inflammation, atrophy, and prostate carcinogenesis. Urologic Oncology: Seminars and Original Investigations; Elsevier, 2007

29. A.A. Quintar, F.D. Roth, A.L. De Paul, A. Aoki, C.A. Maldonado, Toll-like receptor 4 in rat prostate: modulation by testosterone and acute bacterial infection in epithelial and stromal cells, Biol. Reprod., 75 (2006) 664-672.

30. H. Zenick, E. Clegg, S. Perreault, G. Klinefelter, L, Gray, Assessment of male reproductive toxicity: a risk assessment approach. In: W. H, editor. Principles and Methods of Toxicology: Raven Press, New York; (1994) 937-988.

31. N. Marouani, O. Tebourbi, S. Mahjoub, M.T. Yacoubi, M. Sakly, M. Benkhalifa, et al., Effects of hexavalent chromium on reproductive functions of male adult rats, Reprod. Biol., 12 (2012) 119-133.

32. M. Yoshida, T. Kitani, A. Takenaka, K. Kudoh, S. Katsuda, K. Taya, et al., Lack of effects of oxolinic acid on spermatogenesis in young adult and aged Wistar rats, Food Chem. Toxicol., 40 (2002) 1815-1825.

33. F.R. Boockfor, C.A. Blake, Chronic administration of 4-tert-octylphenol to adult male rats causes shrinkage of the testes and male accessory sex organs, disrupts spermatogenesis, and increases the incidence of sperm deformities, Biol. Reprod., 57 (1997) 267-277. 